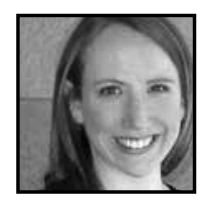

\title{
Gay and Lesbian Families in the Early Childhood Classroom: Evaluation of an Online Professional Development Course
}

\author{
Megan Beren, University of the Rockies
}

\begin{abstract}
Including families is an important theme in the early childhood classroom. Teachers, however, report feeling unprepared when a child's family is composed of same-sex parents. Gay and lesbian families, in turn, feel invisible, silenced, and excluded. Overall, the topic is rarely covered in teacher education programs-in response, an online course on gay and lesbian families was developed. Teachers assessed the knowledge conveyed, comfort with the content, and helpfulness of the tools provided. The findings confirmed that most teachers had received no pre-service or professional development training on the topic. The majority wanted training that included tools for being inclusive and welcoming.
\end{abstract}

\section{Introduction}

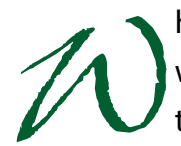

hen families who diverge from the traditional family norm feel included and welcomed into the early childhood classroom, children are introduced to the richness of diversity (Derman-Sparks \& Edwards, 2010). Anti-bias curriculum guides encourage educators to discuss and introduce children as early as possible to diversity, including family diversity, as one means of stemming prejudice, yet many educators have reported feeling discomfort in welcoming families headed by gays or lesbians (Souto-Manning \& Hermann-Wilmarth, 2008). This topic is rarely addressed in teacher training programs, professional development courses, or early childhood curriculum guides (Duke \& McCarthy, 2009; Souto-Manning \& Hermann-Wilmarth, 2008). 
Advocate groups for gay and lesbian parents have argued that books should be present in the classroom, gay historical figures should be discussed, and posters should be displayed on the wall depicting gay and lesbian parents (Burt, Gelnaw, \& Lesser, 2010). Many other groups, including parent groups, have felt strongly that outright activism was inappropriate (King, 2003; Landan, 2009; Rosenblum, 2011). These groups have suggested that non-intrusive acceptance and a school climate that does not tolerate derogatory homophobic comments represent more comfortable options. Currently, guidelines are minimal on how to welcome gay and lesbian families.

\section{Background of the Problem}

Over the last 20 years, the field of early childhood education has increasingly emphasized anti-bias education so that the educational experience of children prepares them for living in a diverse, multicultural world (Derman-Sparks \& Edwards, 2010). In spite of this trend, a stereotype remains that family means White, middle class, English speaking, and living with a mother and a father. Family diversity, however, is no longer an exception; it is the norm. Families vary by culture, ethnicity, religion, and sexual orientation. Obtaining precise data on how many children live in gay or lesbian families is difficult because U.S. census data do not include these families. A Williams Institute analysis of Census 2010 data revealed that 3.8\% of Americans openly identified on surveys as being gay (Williams Institute, 2011). This would translate to nine million people; however, the number of these individuals who are raising children is unknown. The Family Equality Council (2008) reported that one million gay families are raising two million children, yet the Gay, Lesbian, and Straight Educational Network (GLSEN, 2003) reported a far higher number of six to fourteen million children who are estimated to live in gay or lesbian families. Canada does include same-sex couples, both married and common-law, in census data. The 2011 Canadian Census reported 64,575 samesex couples with 6,410 children living at home (www12.statcan.ca). This is an increase of $42.6 \%$ from 2006 and reflects only those willing to identify their sexual orientation. Janmohamed (2010) feels strongly that a "queer perspective" must be brought to early childhood classrooms as "queer parents are a growing demographic in Canada" (p. 310).

While accurate data are not available, these families hope for their children to find inclusion in early childhood centers, but have reported that they have remained silent, not revealing their same-sex status, out of fear their children would experience discrimination from other children or from the staff (Souto-Manning \& Hermann-Wilmarth, 2008). Early childhood educators, in turn, have expressed discomfort in introducing 
this topic in the classroom because of religious, moral, and/or cultural beliefs about same-sex relationships (Duke \& McCarthy, 2009). Some have reported feeling that early childhood is too young an age for this topic or that it is the responsibility of the family, not the school. Others have feared reprisal from other parents, supervisors, or the school district (Souto-Manning \& Hermann-Wilmarth, 2008). Some have advocated for the issue to be included, arguing that avoiding the topic marginalizes, silences, and perpetuates homophobia (Lesser, Burt, \& Gelnaw, 2005).

The topic of welcoming and including gay/lesbian parents in the early childhood classroom is controversial, with minimal research to inform educators. The few educational guidelines that exist were developed primarily by gay/lesbian advocates, yet this is an issue that cannot be ignored, as the number of children estimated to live in gay or lesbian families is increasing (Family Equality Council, 2008). As these children enroll in preschool programs, ideally, teachers should be forming partnerships with their parents because children thrive when parents and schools work together (Lilly \& Green, 2004). The needs of young children require communication, coordination, and trust between families and early childhood teachers (Allen, 2007). While teachers have acknowledged the importance of building partnerships with parents, they have reported feeling unprepared for including gay and lesbian families, as the issue was not addressed in their teacher education programs (Souto-Manning \& Hermann-Wilmarth, 2008; Turner-Vorbeck \& Marsh, 2008). These same teachers have said they would like to know about resources for creating a welcoming, inclusive classroom, as the students with two moms or two dads are often ridiculed, with other children calling their mother and/or father "dyke" or "fag" (GLSEN, Playgrounds and Prejudice, 2012). When pre-service teachers were asked how they defined "family," gay/lesbian families were the least likely to be included in how they constructed their definition of family (Larrabee \& Kim, 2010). This was confirmed by an online opinion poll of 1,099 K-6 teachers. Playgrounds and Prejudice (2012) found that $89 \%$ of the teachers polled said they included representations of different kinds of families, but only $21 \%$ reported any representation of gay and lesbian families. When the students were polled, only $18 \%$ said they had been taught about families with two moms or two dads.

Psychologically based research on lesbian-headed families began in the 1980s, and researchers found that children who grew up in these families were as emotionally healthy as children from single mother-headed or heterosexual families (Flaks, Ficher, Masterpasqua, \& Joseph, 1995; Hoeffer, 1981; Kirkpatrick, Smith, \& Roy, 1981). Educational research, on the other hand, tends to be more ethnographically based. A classic study of competing values emerged when gay parents and a politically conservative superintendent argued vehemently over the use of a curriculum, Children of the 
Rainbow, developed by the New York City Board of Education (1991). This was an early childhood curriculum designed to include gay and lesbian-headed families. Fierce controversy resulted, and the curriculum was eliminated, with the majority of New York City school districts deciding to postpone any mention of lesbian and gay parents until the upper grades. Confrontations emerged in other districts, as well, including Provincetown, Massachusetts (Bedard, 1997), throughout Oregon (Egan, 1992), and more recently in Alameda, California, a suburb of San Francisco (Landan, 2009). The curriculum proposed in California was developed in response to derogatory name calling by children as young as kindergarten age. Ultimately, the curriculum was not adopted because of strong opposition by parents. When school psychologists in New York State completed a survey, they indicated that while gay/lesbian families were visible, they did not perceive the school environment as very open or welcoming for gay/lesbianheaded families (Bishop, 2010).

Overall, minimal research exists at the early childhood level on whether and how to include gay and lesbian parents. One study (Robinson, 2002) conducted in Australia surveyed 49 early childhood educators and found that only a quarter "considered addressing gay and lesbian issues important in developing children's critical thinking and awareness of the broader social, political and economic discrimination that sexual minorities face in their daily lives" (p. 427). Furthermore, Robinson (2002) found teachers believing a "myth that issues affecting the lives of sexual minorities have no bearing or relevance to the lives of heterosexuals" (p. 429). Duke and McCarthy (2009) reviewed multiple databases for studies related to gender and sexuality in early childhood educational settings. Overall, they concluded that only three studies critically examined how teachers could construct "equitable partnerships with LGBT parents in ECE school settings characterized by homophobia, heterosexism and sexism" (p. 400). Interestingly, all three studies were done by members of a gay and lesbian research group at Bank Street College during the 1990s. The researchers asked provocative and challenging questions such as, "To what extent are teachers able to make choices that reflect their educational commitments and to what extent are they limited by the circumstances in which they work?" and "Is it the teacher's role to reflect current societal attitudes or to invite discussion of taken-for-granted attitudes?" (Casper, Cuffaro, Schultz, Silin, \& Wickens, 1996, p. 283). While concluding that change is "a slow process that requires equal parts of patience and persistence," the researchers found teachers who were eager for more training and information (p. 283).

Overall, teachers have felt poorly prepared and frightened of the repercussions of addressing the topic; gay and lesbian families have felt invisible, silenced, and excluded; and children have increasingly heard taunts that are derogatory about 
same-sex attraction. This is a challenging area with strong feelings on both sides of the controversy.

\section{Perspective}

Teachers' discomfort with the inclusion of gay and lesbian families in the classroom has resulted from many interwoven themes. Some have personal prejudicial feelings that have stemmed from a group to which they ascribe (Krueger \& Clement, 1994). Others hold societal stereotypes that were conveyed through their culture, socialization in their family, or repeated exposure to messages transmitted through the media (Brown, 2010). Some have feared they would lose their job if they addressed the topic of same-sex parents through books, posters, or classroom discussion (Souto-Manning \& Hermann-Wilmarth, 2008). In addition, a myth has existed that young children who play in the opposite gender role will grow up to be gay, lesbian, or transgender. Studies have not supported this conclusion. The development of gender identity is in flux during the early childhood years, is complex, and is not yet fully understood (Brill \& Pepper, 2008; Papalia, Olds, \& Feldman, 2007). Reducing prejudice and changing stereotypes are challenging, as strongly held beliefs are difficult to change (Schneider, 2004).

\section{Purpose of the Current Study}

The current study was designed as a preliminary exploration of whether teachers desired training around including gay and families in the early childhood classroom, and if so, in what format and around what topics. Early childhood educators/teachers completed and evaluated an online professional development course I developed entitled, "Gay and Lesbian Families in the Early Childhood Classroom." The course did not advocate for any specific position, but rather educated and stimulated critical reflection by posing dilemmas for self-reflection, dispelling myths from facts, and exposing hidden biases through a classroom vignette. Because this was designed as a standalone course, neither a discussion board nor interactive assignments were included. Following completion of the course, an online survey was used to gather feedback about multiple components of the course. The survey questions focused on past training on this topic, preference for online or in-person training, and which topics in the course provided benefits and which created discomfort. 
The survey also examined teachers' levels of comfort working with gay and lesbian families. Factors that led to differences in teachers' perceptions, such as educational setting, hearing children use derogatory remarks, hearing put-downs around atypical gender role play, as well as age group taught were considered as they related to an interest in training.

\section{Mode of Inquiry}

\section{Participants.}

Early childhood teachers and administrators were invited through an email letter to take an online professional development course and to complete the survey. Private, faith-based, and franchised early childhood programs were included in the sample. These programs were identified from the current list of the National Association of the Education of Young Children (NAEYC). The largest majority of programs were private, and at least 10 of the programs were faith-based.

\section{Procedures}

An email letter was sent to the director of each program explaining the nature of the research and requesting that an accompanying letter be given to individual teachers inviting their participation. Each teacher who was interested in participating first signed an Informed Consent, which then opened an online version of the professional development course. At the completion of the course, a radio button opened the survey. All three were sequenced and linked through Survey Monkey, making them easy for participants to access, complete, and submit online. This assured anonymity, as I had no way of linking survey responses to an individual teacher or to a specific early childhood program. A total of 27 teachers completed the course and the survey.

\section{Data Sources}

The online survey included some preliminary questions to determine whether training on this topic was indeed sparse, and if so, whether early childhood educators had an interest in receiving training. The survey was developed to assess the five components of the course:

- Pro/con provided an overview of the differing opinions on including information about gay and lesbian families in the early childhood classroom. Exploring the pro position, teachers read an advocacy article that appeared in Young Children, a publication of The National Association for the Education of Young Children. The article provides concrete and practical steps to create a culture of inclusion. The full article, "Do No Harm," can be found at http://www.naeyc.org/files/yc/ file/201001/LesserOnlineExtra2.pdf 
Examining the con position, teachers read an excerpt from "Queering The Schools" that vehemently criticized material presented by The Gay, Lesbian, Straight Educational Network (GLSEN) at a conference in 2002. The excerpt is available at http://www.city-journal.org/html/13_2queering-the-schools.html Two films, It's Elementary and That's A Family, are referenced in the article and the link for accessing the trailers of the films was provided: http://groundspark.org/ our-films-and-campaigns

Teachers were asked to reflect on the early childhood center in which they taught and to place their setting on a continuum from the pro position to the con position.

- Difficult Moment presented an unexpected question by a parent requiring a response by the teacher. A short overview of the scenario is provided below:

You are a first-year teacher in a private early childhood center. Two of the children in your classroom come from very loving and supportive same-sex parent families. One of the families brings you the poster shown below and asks you to hang it in the classroom. Reflective questions on how to handle this are posed, such as, "Would you hang the poster and if so, how would you introduce it to the students? What would you say if another family objected? If you decide not to hang the poster, what would you say to the family who brought in the poster?"

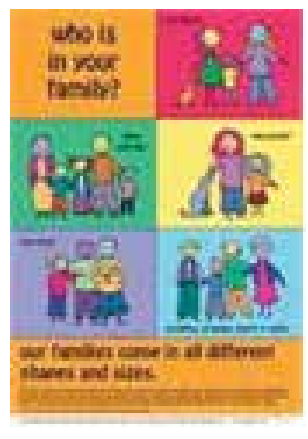

Fig. 1: Rainbow Families Council (2010) 
- Fact or Myth provided research findings that confirmed or disconfirmed common beliefs about gay and lesbian families. For example:

Children raised by same sex couples are more likely to be gay, lesbian, or to experience gender identity confusion as adults.

Children as young as the preschool years are using the word "gay" as a derogatory term in schools.

Each teacher circled whether the statement was a fact or a myth. After responding, the correct answer was provided, on a separate page, with a short paragraph summarizing the research showing the statement to be a fact or a myth.

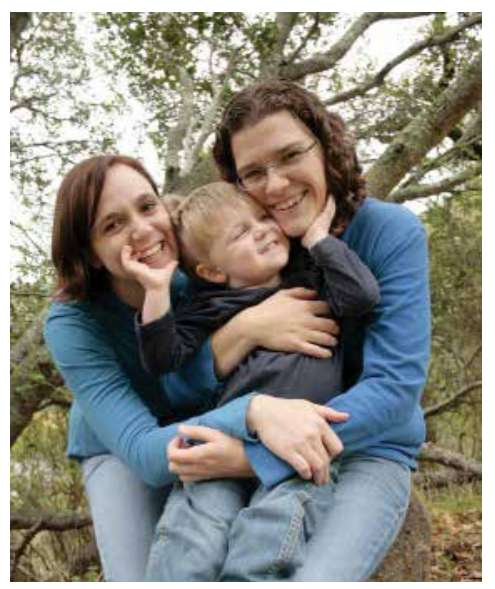

Fig. 2: Family photo-take one

- Hidden Biases included a short scenario in which stereotypical judgments were made about a child who played outside his gender role. Briefly, this scenario actually occurred in a 4-year-old class in New York. Hugh came to class each day, put on a princess costume and told the teachers and other children that he was a girl. The teachers were dismayed and assumed that his gender variant behavior indicated "homosexual transgenderness." While this term does not exist in the literature, the assumption was that Hugh would grow up to be homosexual, transgender, or both. Teachers were asked to reflect on how they might handle such a situation (Williams \& Norton, 2009). 


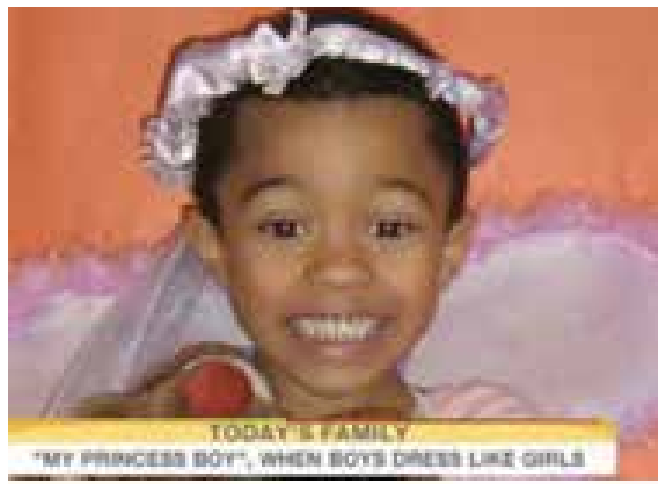

Fig. 3: Dyson Kilodavis on The Today Show, Jan. 3, 2011

- Tools gave teachers ideas for inclusion of gay and lesbian families in a manner that was likely to be acceptable, such as "Take this home to your family," rather than "Take this home to your mother and father" indicated "homosexual transgenderness." While this term does not exist in the literature, the assumption was that Hugh would grow up to be homosexual, transgender, or both. Teachers were asked to reflect on how they might handle such a situation (Williams \& Norton, 2009).

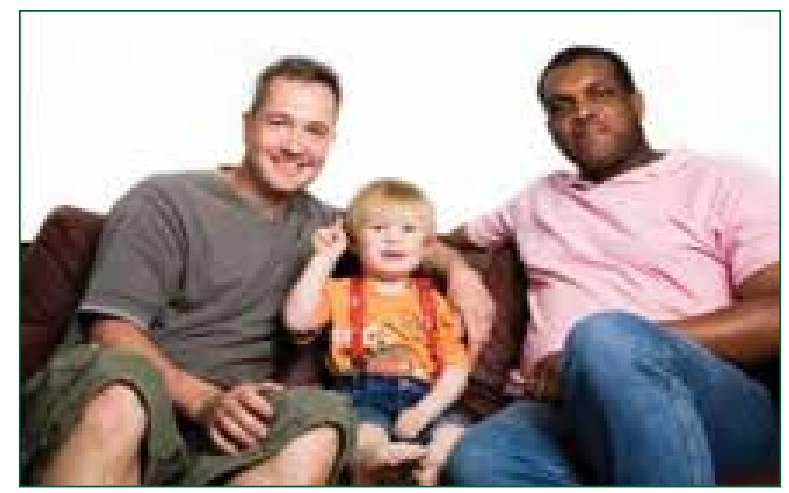

Fig. 4: Family photo-take two

Participants were asked to indicate on a 1 to 4 scale how beneficial each of the five sections of the course was to them. Participants were also asked to indicate, on a five-point scale, their level of comfort with the same five sections of the course. 
Demographic data, such as number of years teaching, gender, age of students, and the characteristics of the early childhood program in which they taught, were collected to determine whether participants' feelings about this topic varied with specific demographics. To assess whether interest in this issue stemmed from current classroom behavior, questions were also posed, such as: Has a child in your classroom ever asked about the issue of same-sex parents? In other words, a child might ask, "How can Deitrich have two dads?" Teachers were also asked about hearing children in their classroom use negative language about gays and lesbians, such as "fag," "faggot," "that's so gay," or "dyke."

The quantitative data from the survey were analyzed with the IBM Statistical Package for the Social Sciences (SPSS), Version 19.0. Descriptive statistics are reported for all variables. Independent-samples $t$-tests were run to determine differences between groups of participants. Significance was determined at the $p=.05$ level.

\section{Results}

The results showed that only two of the teachers had received any training on this topic during their teacher-training program, and only one had received training through a professional development course. Still, 18 teachers indicated that they had gay and lesbian parents in their classroom. As expected, the need for teacher training on this topic is high, and the majority of teachers reported that they would like training, as they felt uncomfortable with the topic.

Less than half of the teachers reported that they had heard the children in their classrooms use negative language about gay and lesbian individuals. Similarly, less than half had heard put-downs directed at children who played outside their gender role. Nevertheless, all but three teachers said they would like suggestions for how to respond if they heard their students demean others around their topics.

Most teachers reported some discomfort to considerable discomfort with the topic of gay and lesbian families. Six reasons for discomfort were described: Lack of training, worry other parents would disapprove, concern for keeping their job, a belief the children were too young, personal feelings, and faith. The top two reasons for teacher discomfort were a lack of training and worry that other parents would disapprove. Personal feelings and faith created some discomfort, but for only seven of the 27 respondents. 


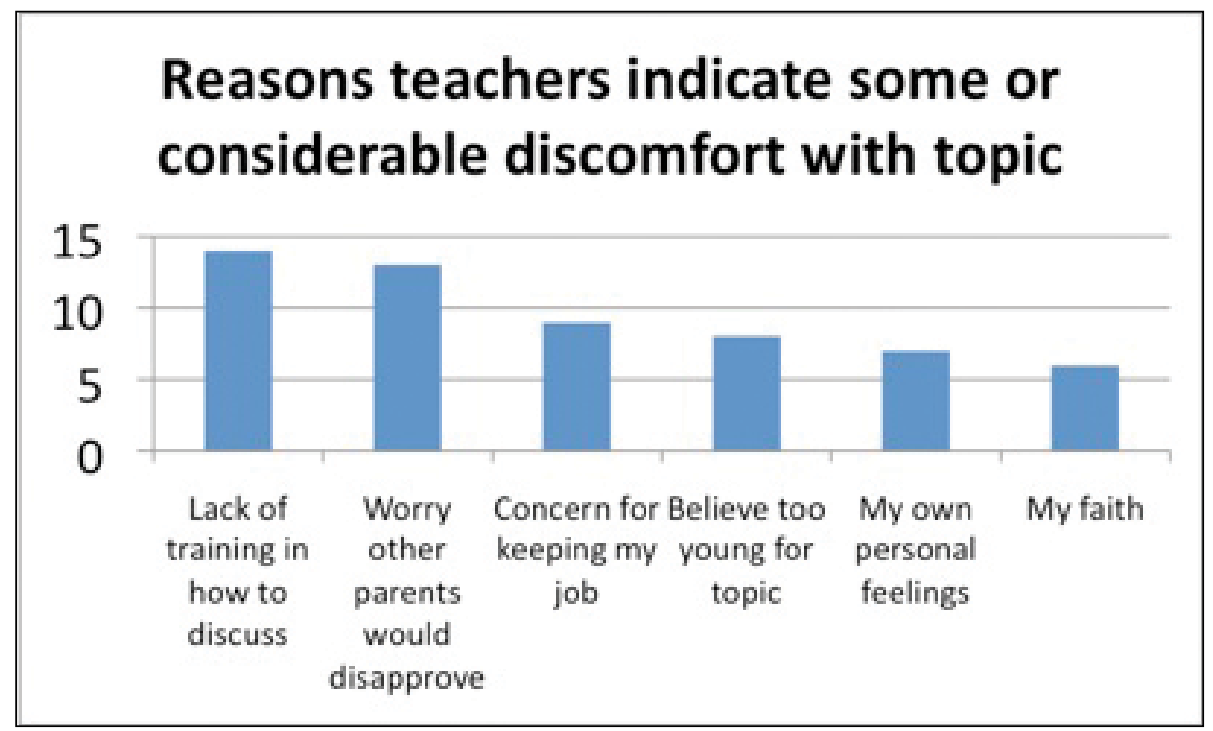

Fig. 5: Reasons for teacher discomfort

Online training was appreciated by the teachers, and $92 \%$ of the respondents indicated that they felt more informed after completing the course.

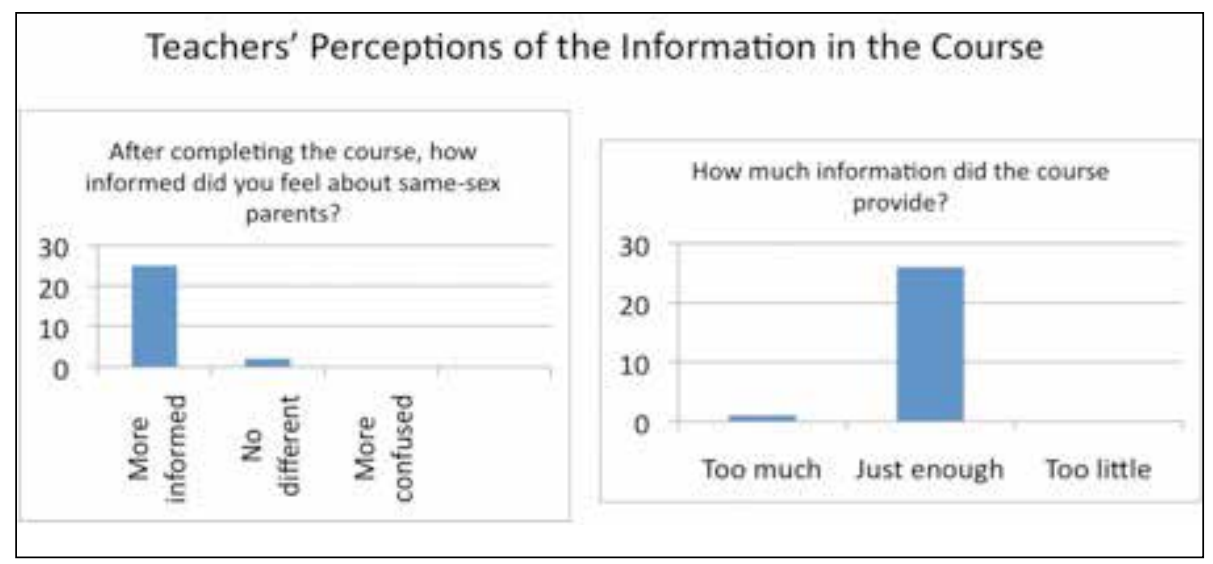

Fig. 6: Teachers' perceptions

The technology was reported as easy to use by $66.7 \%$ and as reasonable by $33.3 \%$ of the teachers. None of the participants indicated that the technology was too difficult. Of the course components, the one found most beneficial was that of having tools to use in the classroom. 


\section{What topics did the teachers indicate would be beneficial to them in this area?}

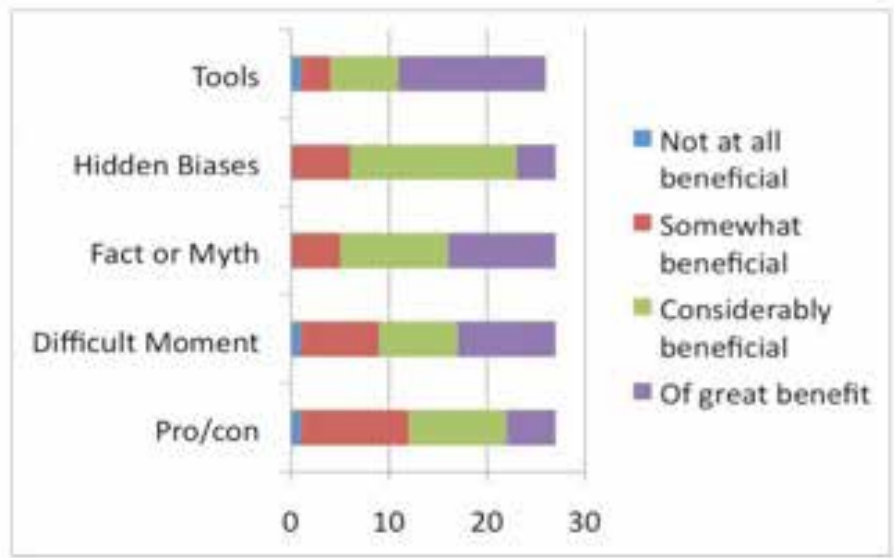

Fig. 7: Topics beneficial to teachers

Overall, the teachers in the study, regardless of their setting, indicated that they would like training on the topic of gay and lesbian families. They reported that their discomfort with this topic stemmed more from a lack of training than from their faith or personal feelings.

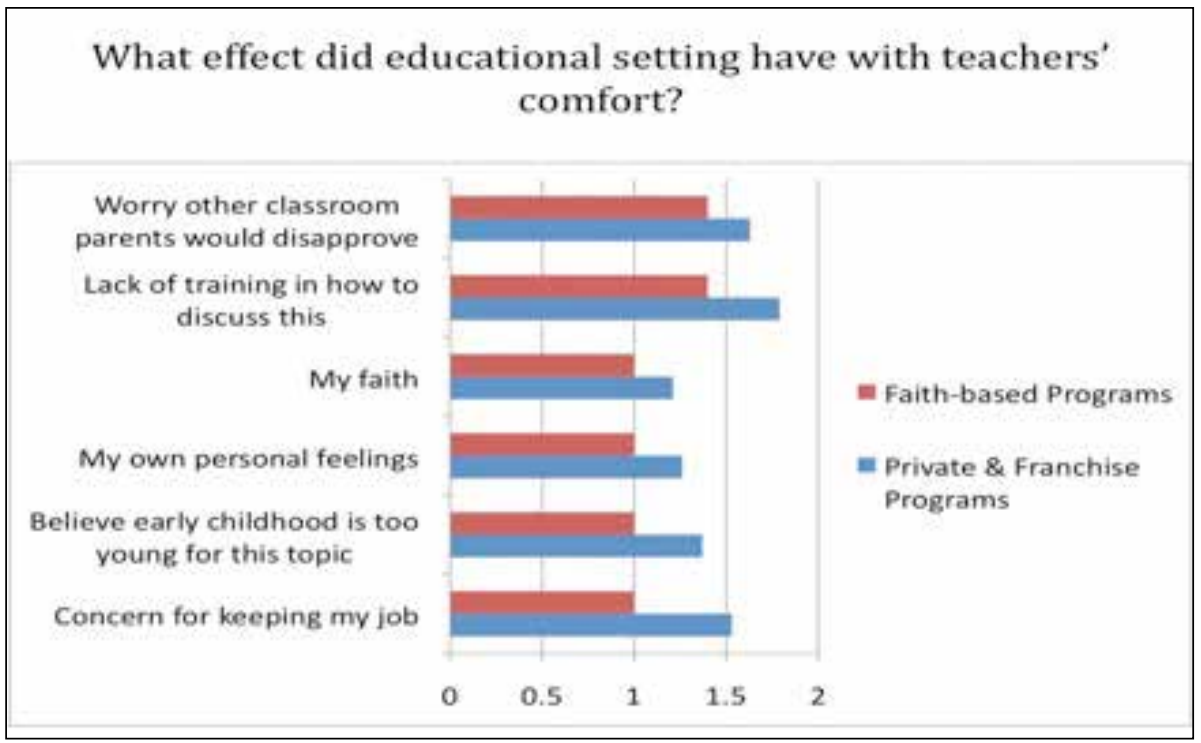

Fig. 8: Impact of educational setting 
Those who confirmed hearing derogatory remarks about homosexuality in their classrooms were more likely to indicate that training would be beneficial.

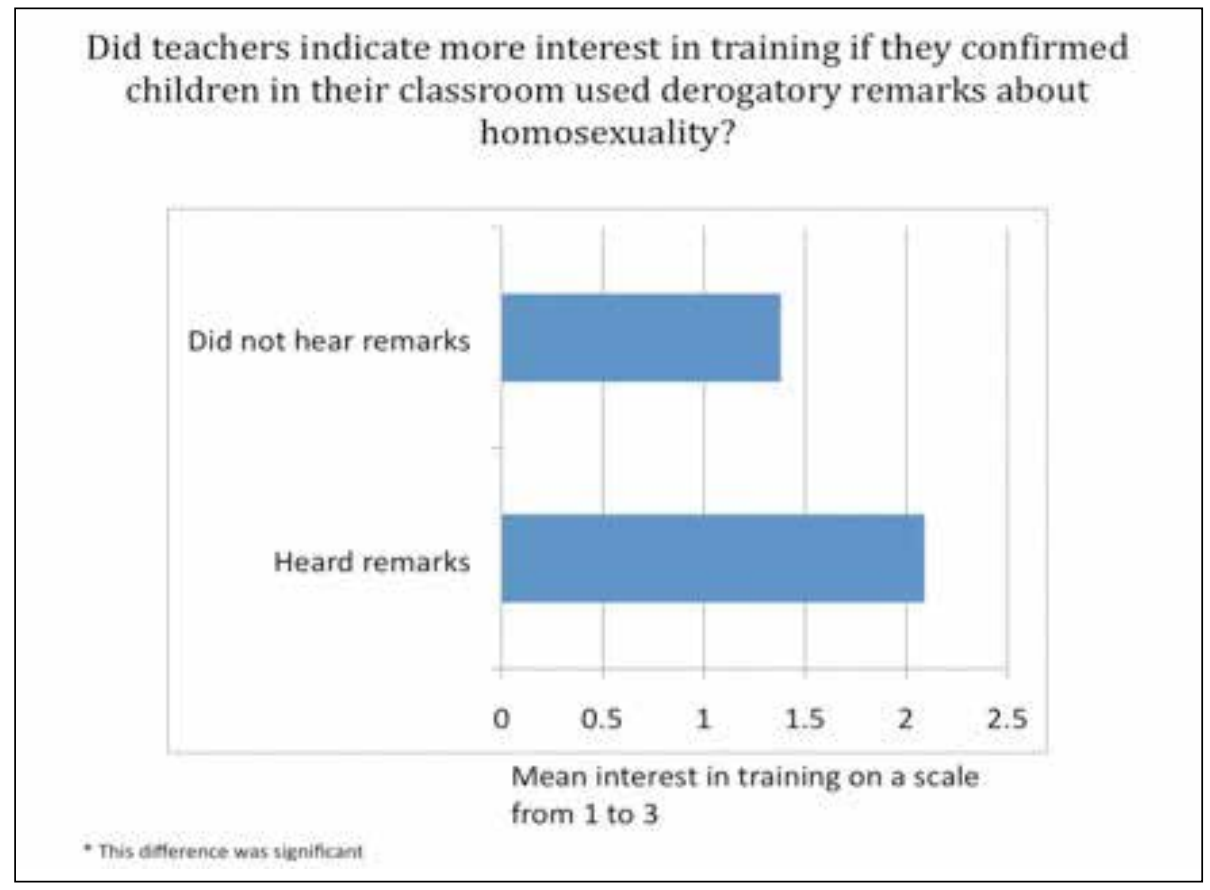

Fig. 9: Use of derogatory remarks in the classroom

Finally, teachers of four- and five-year old children were more interested in suggestions for responding to negative remarks than teachers of younger children. Easy-toimplement tools, such as immediate responses to put-downs or questions from children, held higher interest for teachers than a full curriculum on the topic.

\section{Teacher Reflections}

At the conclusion of the survey, participants were invited to share reflections, thoughts, and any ideas about how the online course could be improved. Ten teachers responded to the invitation. Overall, their comments were positive about both the content of the online course, as well as about their desire to have training, tools, and materials on this topic. One teacher expressed unease with asking for training on this topic. Another teacher felt discomfort with a video clip, It's Elementary, which shows the 
use of a gay/lesbian curriculum in an elementary school. The participants' comments are shared below:

- Helpful information and gave me some additional resources.

- I have much to learn and welcome as much support as possible. I was uncomfortable with the video clip, It's Elementary. Before introducing this topic, I would need to see how the administrators at my school would like to approach the topic.

- I liked this course. Would appreciate more intervention ideas around put-downs.

- I teach in a public school. I would love more tools and material to use.

- I think this topic is very tough.

- I thought this was a very informative and beneficial topic that not many people talk about and should be talked about and discussed more often, as there is a growing population of openly gay and same sex couples.

- Informative course-liked learning online.

- This topic is important but makes me uneasy as a young teacher to bring it up with my center. Nothing was mentioned in my training. More is needed.

- This was a great course. I especially liked the reflections. They made me think.

- Training like this is very needed. This is done tastefully. Some of what I have seen advocates too strongly.

\section{Significance of the Study}

As children from gay and lesbian families are entering early childhood educational programs, many teachers have no training in this area. Most have reported that the topic of welcoming these families was not addressed in their teacher training programs (Souto-Manning \& Hermann-Wilmarth, 2008). Presently, minimal guidelines, tools, or strategies exist for teachers.

Family is an important theme in the early childhood classroom. This is how children make sense of the world and of their own identity. Important messages are conveyed about valuing and respecting differences during these early years. In fact, the preschool classroom may be the first time children with gay or lesbian parents become aware that their family is different than other children's families. Whether to address this issue with young children is controversial. Some teachers have reported that they would like training, while others hold beliefs that the topic is inappropriate at a young age, and is best left to the family (Souto-Manning \& Hermann-Wilmarth, 2008). Regardless of the school's position or the individual beliefs of teachers, there are minimal guidelines, tools, or strategies in this area. What does exist consists of a brief mention of the issue in recent anti-bias curriculums, or lesson plans developed by strong advocates for the 
inclusion of this topic (Burt et al., 2010; Derman-Sparks \& Edwards, 2010). Teachers express concern as they have heard derogatory put-downs being said by children as young as four or five years of age (Kosciw \& Diaz, 2008). These same teachers are acutely aware of the suicides of middle and high school-aged students who have suffered victimization and humiliation for being or even appearing to be gay or lesbian (Espelage \& Swearer, 2008). Tools, strategies, and even entire curricula are slowly emerging to support middle and high school teachers in addressing this issue; however, few exist for the early childhood professional (Burt et al., 2010).

In the past, parent groups voiced strong outcries and vehement opposition when this topic was considered for inclusion in school curriculum (Landan, 2009). Understandably, teachers are uneasy about having books in the classroom that portray gay and lesbian families; about answering questions posed by their students; and about how to address, welcome, and include a lesbian mother and her partner or two daddies (Casper \& Schultz, 1999).

\section{Summary of Findings}

Overall, the findings from this study confirm that most teachers in the study, regardless of the educational setting in which they taught, wanted training on the topic of gay/lesbian families. This topic was not addressed in their teacher training programs or in their current job setting. They felt they lacked guidelines, tools, or strategies, which left them feeling uncomfortable. Most of all, the teachers wanted tools for how to be inclusive and welcoming, without specifically discussing the topic with the children via a comprehensive curriculum. Diversity training of the type that includes examining personal biases, reflecting, and becoming aware of hidden institutional/societal stereotypes was not the type of training that the early childhood educators in this study found appealing. Rather, they indicated that they appreciated having the summary of research findings provided to them, as was done in the Fact or Myth section.

When asked about having articles for their own reading, the respondents showed low interest. Having books in their classroom on the topic was controversial. Some said they would like recommendations of picture books on the topic, while others felt uncomfortable with any books unless approved by the principal or administration. Online training was endorsed by a large majority of the teachers; however, they were self-selected. They were comfortable with the technology necessary to complete a stand-alone course, and they were willing to set aside 30 to 45 minutes of their time to 
participate in the study. Online professional development and learning in areas not covered in teacher training programs appears to be an important new direction to assure that teachers have the preparation for creating an inclusive and welcoming classroom for all children. It is important to note the limitations of this exploratory study, which included a small sample size from a limited area, as well as self-selected participants.

\section{Recommendations for Practice}

The most potent suggestion from this study is that urgently, teacher education programs need to include training in the inclusion of gay/lesbian families. Furthermore, since most teachers received no training during their teacher education, professional development courses and in-service training are also essential for those currently teaching. Training needs to be done in a developmentally appropriate manner with a specific focus on early childhood educators. Robinson and Ferfolja (2008) found that this topic was rarely addressed in pre-service teacher education because of "childhood innocence," and a belief that early childhood education spanned too young an age. Casper and Schultz (1999) attributed this belief to the theories and research of developmental psychologists who have imparted the notion that children are too young for adult social issues, and accordingly educators want to shield them from such issues. Furthermore, they pointed out that what is change for adults may not be so for children: "Many children have never known a world without lesbian and gay families" (p. 12). Overall, data from the current study found that this topic was not discussed in teacher education programs and this lack of training was the primary reason that teachers indicated discomfort with the topic.

More than half of the teachers, who had observed children using derogatory language, or playing outside of their gender role, indicated that these observations were not primary reasons for their interest in training. Rather, the teachers appeared to desire training because they felt uncomfortable discussing the topic. Most of all, teachers wanted tools and strategies for including gay and lesbian families; they were not interested in utilizing an explicit curriculum on the topic. Their preference was for ways to be welcoming to same-sex families without specifically introducing the topic to the children. Regardless of setting, teachers indicated not only a strong desire for training, but also for guidelines from the administration on whether to directly discuss the topic. They wanted the school director to define the climate of the school and to decide whether books on the topic could be in the classroom. They also wanted suggestions about how to respond to direct questions from young children on the topic. 
The teachers indicated a strong interest in online training; however, the teachers who completed the online course self-selected and were not drawn randomly. It is possible that those who had more interest completed the course and the survey. Some potential participants may have opened the course, found it of no interest for any number of reasons, and then opted out without completing the course or the survey. More research is needed on whether online learning is a preferred modality for conveying knowledge around controversial topics rather than school-wide professional development forums or seminars. The anonymity of an online course may allow more comfort with a difficult topic than a participatory professional development course with colleagues.

In addition, more research with larger samples from different geographical locations would confirm how this interest varies by urban and rural areas, regions of the country, and among different ethnic groups. A qualitative study using interviews would allow more directive questions and explanatory responses, which would clarify the training wishes of early childhood teachers. More specific knowledge would benefit those designing training programs to match the interests and needs of educators.

\section{References}

Allen, J. (2007). Creating welcoming schools: A practical guide to home-school partnerships with diverse families. New York: Teachers College Press.

Bedard, P. (1997, August 21). Provincetown preschoolers to learn $\mathrm{ABCs}$ of being gay. The Washington Times, p. A1.

Bishop, C. (2010). How visible and integrated are lesbian, gay, bisexual, and transgender families: A survey of school psychologists regarding school characteristics (Doctoral dissertation). Retrieved from http://www.proquest.com. cardinal.fielding.edu/en-US/products/ dissertations/individuals.chtml

Brill, S., \& Pepper, R. (2008). The transgender child. San Francisco: Cleis Press.

Brown, R. (2010). Prejudice: Its social psychology. London: Wiley-Blackwell.

Burt, T., Gelnaw, A., \& Lesser, L. (2010, January). Do no harm: Creating welcoming and inclusive environments for lesbian, gay, bisexual and transgender (LGBT) families in early childhood settings. Young Children. Washington, DC: National Association for the Education of Young Children (NAYEC). Retrieved from http://www.naeyc.org/yc/ pastissues

Canadian Census. Retrieved from http://www12. statcan.ca

Casper, V., Cuffaro, H., Schultz, S., Silin, J., \& Wickens, E. (1996). Toward a most thorough understanding of the world: Sexual orientation and early childhood education. Harvard Educational Review, 66(2), 271-294.

Casper, V., \& Schultz, S. (1999). Gay parents/ straight schools. New York: Teacher's College Press.

Derman-Sparks, L., \& Edwards, J. (2010). Anti-bias education for young children and ourselves. Washington, DC: National Association for the Education of Young Children. 
Duke, T., \& McCarthy, K. (2009). Homophobia, sexism, and early childhood education: A review of the literature. Journal of Early Childhood Teacher Education, 30(4), 385-403.

Egan. T. (1992, August 16). Oregon measure asks state to repress homosexuality. The New York Times, pp. A1, A34.

Espelage, D., \& Swearer, S. (2008). Addressing research gaps in the intersection between homophobia and bullying. School Psychology Review, 37(2), 155-159.

Family Equality Council. (2008). Retrieved from http://www.familyequality.org

Flaks, D., Ficher, I., Masterpasqua, F., \& Joseph, C. (1995). Lesbians choosing motherhood: A comparative study of lesbian and heterosexual parents and their children. Developmental Psychology, 31(1), 105-114.

GLSEN (Gay, Lesbian, and Straight Education Network). (2003). One umbrella, many people: Diversity within the LGBT communities. Retrieved from http://www.glsen.org

GLSEN (Gay, Lesbian and Straight Education Network). (2012). Playgrounds and prejudice: Elementary school climate in the United States. New York: GLSEN and Harris Interactive.

Hoeffer, C. (1981). Children's acquisition of sexrole behavior in lesbian-mother families. American Journal of Orthopsychiatry, 51(31), 536-543.

Janmohamed, Z. (2010). Queering early childhood studies: Challenging the discourse of developmentally appropriate practice. The Alberta Journal of Educational Research, 56(3), 304-318.

King, M. (2003, Spring). Queering the schools. City Journal. Retrieved from http://www. city-journal.org/html/13_2_queering_the_ schools.html

Kirkpatrick, M., Smith, C., \& Roy, R. (1981). Lesbian mothers and their children: A comparative study. American Journal of Orthopsychiatry, 51(3), 545-551.

Kosciw, J., \& Diaz, E. (2008). Involved, invisible, ignored: The experiences of lesbian, gay, bisexual and transgender parents and their children in our nation's K-12 schools. New York: Gay, Lesbian and Straight Educational Network (GLSEN).www.glsen.org.
Krueger, H., \& Clement, R. (1994). Memory-based judgments about multiple categories: A revision and extension of Tajfel's accentuation theory. Journal of Personality and Social Psychology, 67, 35-47.

Landan, K. (2009, May 22). Gay curriculum proposal riles elementary school parents. Fox News. Retrieved from http://www.foxnews. com/printer_friendly_story/0,3566, 521209.00

Larrabee, T., \& Kim, Y. (2010). Preservice elementary teachers' perceptions of family: Considering future instruction on lesbianand-gay-headed families. Journal of Research in Child Education, 24, 351-365.

Lesser, L., Burt, T., \& Gelnaw, A. (2005). Making room in the circle: Lesbian, gay, bisexual and transgender families in early childhood settings. San Rafael, CA: Parent Services Project.

Lilly, E., \& Green, C. (2004). Developing partnerships with families through children's literature. Upper Saddle River, NJ: Pearson.

New York City Board of Education. (1991). Children of the rainbow: First grade. New York: Board of Education of the City of New York.

Papalia, D., Olds, S., \& Feldman, R. (2007). Human development (10th ed.). Boston: McGraw Hill.

Rainbow Families Council. (2010). Retrieved from http://www.glhv.org.au/fact-sheet/"whoyour-family"-resource-kit-rainbow-familiescouncil.

Robinson, K. (2002). Making the invisible visible: Gay and lesbian issues in early childhood education. Contemporary Issues in Early Childhood, 3(3), 415-431.

Robinson, K., \& Ferfolja, T. (2008). Playing it up, playing it down, playing it safe: Queering teacher education. Teaching and Teacher Education, 24, 846-858.

Rosenblum. L. (2011, Spring). Don't teach children about homosexuality. Teaching for Tolerance, 6-7.

Schneider, D. (2004). The psychology of stereotyping. New York: Guilford Press.

Souto-Manning, M., \& Hermann-Wilmarth, J. (2008). Teacher inquiries into gay and lesbian families in early childhood classrooms. Journal of Early Childhood Research, 6(3), 263-280. http://ecr.sagepubl.com/content/6/3/263 
Turner-Vorbeck, T., \& Marsh, M. (2008). Other kinds of families: Embracing diversity in schools. New York: Teacher College Press.

Williams Institute. (2011). Census \& LGBT demographic studies. Retrieved from http://www. williamsinstitute.law.ucla.edu/category/ research/census-Igbt
Williams, L., \& Norton, N. (2009). Thought provoking moments in teaching young children: Reflections on social class, sexuality and spirituality. In C. Genishi \& A. Goodwin (Eds.), Diversities in early childhood education (pp. 103-118). New York: Routledge.

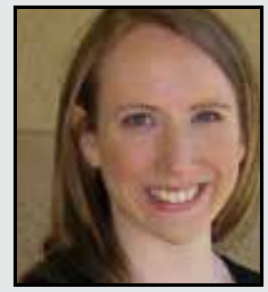

Megan Beren has an M.S. in Early Childhood Education from Sarah Lawrence College and an Ed.D. in Educational Leadership and Change from Fielding Graduate University. While living in the United Kingdom, online learning provided a means for staying connected to the educational community in the United States. Upon returning, she completed a certificate, "Teaching in the Virtual Classroom," and began developing online courses in family diversity. Currently, Megan holds a position as adjunct faculty at University of the Rockies. 